\title{
FIRM HETEROGENEITY, JOBS, AND \\ INTERNATIONAL TRADE: EVIDENCE \\ FROM CHILE
}

James Levinsohn

Working Paper 5808

\section{NATIONAL BUREAU OF ECONOMIC RESEARCH 1050 Massachusetts Avenue \\ Cambridge, MA 02138 \\ October 1996}

I am grateful to Wei Fan, Marc Melitz, Amil Petrin, and Claudia Sever for superb research assistance. I am also grateful to Chris Foote for helpful discussions. John Hamm, Gordon Hanson, Mike Knetter, John Leahy, Ed Leamer, and Matthew Slaughter provided helpful suggestions. Research support from CIBE at the University of Michigan Business School and the World Bank is gratefully acknowledged. This paper is part of NBER's research program in International Trade and Investment. Any opinions expressed are those of the author and not those of the National Bureau of Economic Research.

(C) 1996 by James Levinsohn. All rights reserved. Short sections of text, not to exceed two paragraphs, may be quoted without explicit permission provided that full credit, including $\mathbb{C}$ notice, is given to the source. 
NBER Working Paper 5808

October 1996

\title{
FIRM HETEROGENEITY, JOBS, AND \\ INTERNATIONAL TRADE: EVIDENCE \\ FROM CHILE
}

\begin{abstract}
This paper is about jobs and international trade. It is about what researchers can learn of the relationship between the two using firm-level data. It is about the particular experience of Chile following a broad trade liberalization and spanning significant macroeconomic contraction and expansion. Finally, this paper is about discerning patterns in the data that might later influence how international economists model the interaction between international trade and employment.
\end{abstract}

James Levinsohn

Department of Economics

University of Michigan

Ann Arbor, MI 48109

and NBER

JamesL@umich.edu 


\section{Firm Heterogeneity, Jobs, and International Trade: Evidence from Chile \\ James Levinsohn \\ University of Michigan \\ National Bureau of Economic Research}

\section{Introduction.}

This paper is about jobs and international trade. It is about what researchers can leam of the relationship between the two using firm-level data. It is about the particular experience of Chile following a broad trade liberalization and spanning significant macroeconomic contraction and expansion. Finally, this paper is about disceming pattems in the data that might later influence how intemational economists model the interaction between international trade and employment.

Empirical studies of the impact of intemational trade on jobs are not scarce. Recent (but already dated) summaries of this literature are found in Deardorff and Hakura (1994) and Leamer and Levinsohn (1995). The point-counterpoint debate of "Trade matters" versus "No, it doesn't" has continued with a series of papers by Edward Leamer (matters) and Paul Krugman (doesn't really matter.) See for example Krugman and Lawrence (1993), Krugman (1995), Leamer (1994), Leamer (1996) and the papers cited therein. Although this literature is rife with discord, there are a few common threads to most all of the studies. First, most of these studies focus on the United States. Second, when data is used, it tends to be industry-level data. Both threads are understandable yet potentially misleading.

Given the availability of U.S. data and the high profile of the trade and jobs debate in the U.S., it is understandable that researchers have focussed most of their efforts on studies using U.S. data. On the other hand, the U.S. is a somewhat goofy choice of countries in which to look at the impact of trade on either jobs or wages. Most econometric studies use data with a time-series component. Intertemporal variation in such data may be generated by exchange rate shifts and trade policy shifts. In the case of the former, many industries exhibit very muted exchange-rate pass-through. In the case of the latter, the U.S. has had a relatively stable trade policy over the last couple decades. There is not likely to be a huge amount of variation in the data and this makes identification subtle and estimates fuzzy. Also, one argument made by the Krugman side of the trade and wages debate is that the quantity of international trade in the U.S.

\footnotetext{
I am grateful to Wei Fan. Marc Meliz. Amil Petrin and Claudia Sever for superb research assistance. I am also grateful to Chris Foote for helpful discussions. John Hamm, Gordon Hanson, Mike Knetter, John Leahy, Ed Leamer, and Matthew Slaughter provided helpful suggestions. Research support from CIBE at the University of Michigan Business School and the World Bank is gratefully acknowledged.
} 
economy is just not big enough to generate big effects on trade and wages. A logical implication of this is that if one wanted to find larger effects of trade, it might help to look at economies significantly more open than the U.S. The amount of variation in intemational competition and level of trade each suggest that looking for trade effects on employment or wages in the U.S. is like looking for Spam on the menu at the Russian Tea Room. If you want Spam, head to the soup kitchen and if you want to look for the trade effects on employment outcomes, look to a country like Chile.

The use of industry-level data is also an understandable but goofy choice. It is understandable because it is what is most commonly available. But it is goofy since industries don't hire (or fire) workers and pay wages, firms do. One of the points of this paper is that the aggregation from firms to an industry is not innocuous. There are a number of important issues that simply cannot be addressed with industry-level data, and there are yet more issues where the use of such data may give misleading answers.

In the first category are questions such as "What are the effects of liberalization on industry concentration?" Suppose it tums out that under liberalization small firms go out of business while large ones expand. This has policy implications but the issue will not arise with industry-level data. Or "Should trade adjustment assistance be targeted at small or large firms?" Suppose it tums out that that a disproportionately large fraction of job creation is done by smaller firms. This would be an important factor for policy makers to take into account if they are going to offer any trade adjustment assistance. Targeting larger firms for job creation programs such as retraining or employment subsidies is administratively easier than going after the small firms, but may be quite off the mark. On the other hand, if it is large firms that create most of the jobs, the argument goes the other way. Or, finally, "How has the skill composition of jobs changed?" Suppose most of those who lose their jobs after liberalization are unskilled workers and most new jobs are filled by skilled workers and/or managers. Then there is a stronger case for including a retraining component to trade liberalization.

The second category of questions are those where the use of industry-level data may give misleading answers to questions conceming the effect of trade on jobs. Using industry-level data implicitly means focusing on net employment changes. For example, if the effect of trade liberalization is to reallocate jobs within an industry leaving the net employment about the same, industry-level data will be unable to detect this reallocation. One might then erroneously conclude that trade had little to no impact on jobs when in fact a large fraction of the workforce's experience would suggest otherwise.

The remainder of this paper is organized as follows. Section 2 provides some background on the Chilean experience with trade liberalization and describes the data used in this paper. Some descriptive statistics are also provided. A framework for examining employment growth with firm-level data is then introduced in Section 3. That framework is employed to non-parametrically investigate how job growth varies by trade 
orientation. It is shown that there is much heterogeneity in employment outcomes across firms within an industry. Section 4 further investigates this phenomenon of simultaneous job creation and job destruction. Section 5 addresses the issue of persistence. Of jobs created, how long do they last, and are lost jobs really gone forever? Section 6 addresses the question, "Where have all the new jobs gone?" Have the new jobs appeared in exporting industries while the lost ones came from import-competing industries? Section 7 examines changes in the skill composition of employment, while Section 8 concludes.

\section{Trade liberalization in Chile: Background and Data}

Throughout the 1960's and early 1970's Chile pursued a policy of import-substitution. ${ }^{1}$ This policy regime was characterized by high tariffs, restrictive quotas, a complicated set of over-valued exchange rates, and other regulations, often focussed on credit, that made imponting onerous and expensive. Tariff rates in the mid-1970's averaged about 105 percent (The World Bank (1989)) while effective rates of protection averaged over 150 percent in 1974 (Corbo and Sanchez (1985).)

In 1973, Pinochet came to power and the economic environment changed dramatically. Fiscal austerity was introduced and a more outward-oriented set of economic policies was introduced. This liberalization had five key components. First, quantitative trade restrictions were removed. Tariffs were reduced in three steps. By 1975 , the maximum tariff had been reduced to $120 \%$ with an average tariff rate of $57 \%$. By August 1977, tariffs ranged from 10 to $35 \%$, and by June 1979, a uniform 10 percent tariff (excepting motor vehicles) had been implemented.

The second aspect of the liberalization focussed on privatizing firms previously held by the government. By 1978, all banks except one and most firms had been privatized. The third aspect of liberalization was a relaxing of some 3000 government controlled prices. Fourth, financial markets were reformed. This involved letting the market set interest rates and, by 1980 , removing almost all quantitative restrictions on external borrowing. Finally, the liberalization removed much of the control of labor unions, and labor recruitment practices became more market-driven.

These liberalizing measures were accompanied by contractionary macroeconomic policies. These policies, coupled with a decline in copper prices and the oil shocks led to a severe recession that lasted through 1975. A recovery from 1976 to 1981 followed. The Latin American debt crisis led to another recession in 1982-83 during which industrial output and employment fell. In response to this contraction, tariff rates rose to an average of around 34 percent but were then gradually scaled back to around 15 percent. Industrial output rose again in 1984, stalled in 1985, and then continued to rise throughout the decade. The

\footnotetext{
1 This section on country background draws heavily on Roberts and Tybout (1995) and Lui (1991).
} 
broad picture is one in which liberalization was drastic and mostly complete by 1979 , the first year of the data set.

The adjustment to the trade liberalization and the large macro shocks led to significant variation in the real exchange rate. Using the IMF's calculation of an index of the real effective exchange rate, the Chilean peso was at 171.3 in 1979. It rose (appreciated) to 199 in 1980 and to 235 in 1981. It then began a steady depreciation and in 1987 was at 107 . One might expect this substantial variation over the sample period to impact firms in import-competing and in exporting industries quite differentially.

The data set is comprised of plant-level data of 6665 plants in Chile from 1979 to 1986 . The data are essentially a manufacturing census covering all firms with at least ten employees. The data were originally provided by Chile's Instituto Nacional de Estadistica (INE) and have since been used in a World Bank study on productivity and trade liberalization. See Roberts and Tybout (1995). A very detailed description of how the eight longitudinal samples were combined into a panel is found in Lui (1991). The structure of the data set is an unbalanced panel. That is, there is detailed information tracking plants over time and the data set includes plants that enter over the course of the sample period (births) as well as plants that exit (deaths.) ${ }^{2}$ The aspect of the data set that this study most exploits is the detailed information about plant employment, both in the aggregate and by gender and skill level.

Some descriptive statistics on plant-level employment are given in Table 1. There are three main messages from this Table. The first message is about the pattem of employment over the business cycle. The macroeconomic contraction and subsequent rebound are apparent in Table 1. Total manufacturing employment fell monotonically from 1979 to 1983 and then increased monotonically until the end of the sample. Net manufacturing employment fell about 9.6 percent over the sample. In 1979, there were 5306 plants in the sample, while by 1983 , this number had fallen to 3900 . Mean plant employment was reasonably stable in the mid-50's over the contraction. 1984 and 1986 were, from a macroeconomic perspective, expansionary years, and over this period the number of firms remained basically flat while employment per firm increased substantially. The general pattem in the data's first moments is one in which plants exited over the contraction and existing plants then expanded during the rebound. This resulted in industry consolidation.

The second message of Table 1 concerns the relationship between the number of plants, mean employment, and trade orientation. (Trade orientation, in this data set, is defined at the industry-level, not the plant-level. i.e. There is not data on whether individual plants actually exported, only whether the industry of which they were a part were net exporters.) There are almost four times as many plants

\footnotetext{
2 Because the data only include plants with at least ten employees, births could be existing firms that previously had fewer than ten employees but which cross the sample threshold. The analogous case holds for deaths.
} 
in the import-competing sector than there are in the exporting sector. The average employment at a plant in the export sector, though is about 50 percent greater than the average employment of plants in the import-competing sector. Plants in the non-tradeables sector, however, have on average about 25 percent fewer employees than plants in the import-competing sector. There is perhaps weak evidence that plants in the export sector might have experienced higher employment growth than plants in the import-competing sector. The ratio of total export sector employment to total import-competing sector employment rises almost monotonically throughout the sample (from .387 in 1979 to .492 in 1986.)

The last and most important message in Table 1 concems not first but second moments of the job data. Standard deviations swamp means. Within any given trade classification, plant-level heterogeneity is quite large. This suggests that only examining the means of overall employment may be misleading. The next section of the paper introduces a framework for examining employment in light of the significant plant-level heterogeneity.

\section{Employment Growth and Plant Heterogeneity}

The plant-level heterogeneity suggested by Table 1 raises a number of policy-relevant and theoretically interesting issues. Instead of just examining whether the aggregate sectoral employment levels increased or decreased, one can address issues concerning the distribution of plant-level employment. For example, what role do entry and exit play in the distribution of employment growth rates? Are decreases in sectoral employment due mostly to plant exit or less drastic employment decreases by surviving plants? Correspondingly, how important are new plants in accounting for employment expansion? And how do the answers to these questions vary by trade classification and firm size?

To begin to examine employment flows more carefully, some notation is required. I follow the general set-up of Davis and Haltiwanger (1992). Denote the employment at plant $i$ in year $t$ as $x_{i t}$. Then define the average employment at the plant as:

$$
x_{e t}=\frac{1}{2}\left(x_{i, t}+x_{i, t-1}\right) \text {. }
$$

The growth rate of employment at a plant, $g_{e t}$, is given by:

$$
g_{e t}=\frac{x_{i t}-x_{i, t-1}}{x_{e t}}
$$

This formulation has the nice property that it easily accommodates births $(g=2)$ and deaths $(g=-2)$ of plants.

Whereas Table 1 looked at levels of employment, Table 2 begins to address the issue of changes in employment using the plant-level data. Most of the messages of Table 1 are echoed in Table 2. There is 
much inter-temporal variation in employment growth rates and the inter-temporal variation is greater than the variation by trade orientation. Employment shrank more in the export sector than in the import sector during the contraction and rebounded more vigorously during the subsequent expansion. The non-tradeables sector never fully engaged in the recovery. A comparison of Tables 1 and 2 reveals that while mean plant employment increased for plants in the non-tradeables sector, average growth rates were negative, and this highlights the importance of exit in this sector. The most surprising aspect of Table 2 concerns what is not seen in the table. Comparing the mean employment growth rates of plants in the import-competing and export sectors for a given year shows remarkably little difference. If one expects to see employment booming in the export sector and shrinking in the import-competing sector in the years following the trade liberalization, Table 2 ought to surprise. Finally, Table 2 again highlights the importance of plant-heterogeneity as the standard deviation of the growth rates is quite large. Twice the standard error spans almost the entire range of growth rates (which, recall, only vary from -2 to 2 .)

The large standard deviations of mean plant employment in Table 1 suggest that firm size is widely distributed. Table 2 suggests that firms in import-competing and export sectors responded somewhat similarly to the macroeconomic cycles in Chile and that trade orientation did not seem to matter much. Combining these two observations raises the question of whether employment at small and large plants responds similarly to the combination of trade liberalization and business cycles. Table 3 begins to address this issue. Table 3 reports job growth rates by trade orientation and by plant size. Plants were divided into quintiles depending on their average employment. If Table 2 was striking because trade orientation did not seem to matter much, Table 3 is striking because plant size does. Within a plant-size quintile, trade orientation does not seem to have a large impact on employment growth. That is, means along a row are quite similar. Within a given trade orientation, plant size really does seem to impact employment growth rates. Smaller firms have noticeably lower employment growth rates than larger firms.

\section{Nonparametric Evidence}

This point can be made more formally using standard non-parametric methods. The empirical density of growth rates for all firms is given in Figure 1. As Tables 2 and 3 suggest, though, this distribution hides significant differences across firm size, although it tums out that the distributions for import-competing and exporting firms are remarkably similar. A statistical test that is reasonably robust to the underlying distribution of growth rates is the Wilcoxon rank-sum test. ${ }^{3}$ This test tests the hypothesis that two samples are drawn from populations with the same underlying median. A nice discussion of this test is found in

\footnotetext{
3 This test assumes that the underlying distribution is symmetric. Kemel density estimates of the relevant distributions suggest this
} assumption is, in this case, reasonable. 
Sprent (1993). To compute the Wilcoxon rank-sum test, the firms have to be divided into two groups. This division was made four ways. One division put firms in import-competing industries in one group and firms in exporting industries in another group. The other three divisions were export versus non-tradeables, import versus non-tradeables. and big versus small. For the latter, the population was divided into groups depending on whether average firm size was above or below the median firm size. Results are summarized in Table 4.

One cannot reject the hypothesis that the median employment growth rate of firms in the import and the export sectors are the same. Median employment growth rates for firms in both the import and export sectors are significantly different than the median employment growth rate of firms in the non-tradeables sector. In these cases, the z-statistics are about 2.7. The strongest evidence of different medians, though, comes when the sample was divided according to firm size, as the $\mathrm{z}$-statistic in this case is 7.21 .

In addition to having significantly different medians, the shape of the empirical distribution of growth rates differs for small and large firms in a way that it does not when comparing firms by trade orientation. This is illustrated in Figure 2. Figure 2 gives kemel density estimates of the distribution of growth rates for firms in the first and last quintiles where quintiles are defined by average firm size. An Epanechinikov kemel is used and the bandwidth for each density estimate was .03. The results, though, are robust to several other kemels. ${ }^{4}$ The density estimates imply that small firms are almost three times as likely to exit the sample, while new entrants are (not surprisingly) more likely to be small than quite large. Small firms also adjust employment less frequently than large firms.

We have seen evidence suggesting that the distribution of job growth varies more by firm size than by trade orientation. The next question is how important the different size classifications are to overall job creation and destruction. That is, do smaller firms account for many of the jobs created or lost or are the largest firms much more important? This is an important concem for trade adjustment and job retraining programs, for it addresses the issue of where to focus such efforts. Figures 3 and 4 address these concems. Firms were ranked based on average employment, divided into 20 equally sized groups, and the fraction of job creation and destruction due to each group is graphed. Figure 3 contains all import-competing firms, while Figure 4 includes all export sector firms.

The basic messages are the same in both Figures. For example, the largest 5 percent of the firms in each sector account for a very large fraction of all job creation and destruction. The extreme case is job creation in the export sector where the largest 5 percent of plants accounted for almost 45 percent of all job creation. From a policy perspective, this suggests that concentrating trade adjustment or job creation incentives to the

\footnotetext{
4 Since these methods are not often used in international trade, the interested reader is referred to Silverman (1986) for a very readable introduction to density estimation.
} 
largest handful of firms is probably a very efficient strategy, for that is where most of the jobs are being created and destroyed. For both import-competing and export sectors, it is also true that within smaller size classes, the fraction of jobs destroyed is almost always greater than the fraction created. (In the export sector, this is true of almost every size class except the largest five percent.) Job creation is disproportionately in the larger firms, while job destruction is disproportionately in the smaller firms. This is again consistent the the overall pattem of industry consolidation seen in Table 1. In the U.S., there has been much discussion about whether smaller firms contribute disproportionately to job creation. In the Chilean case, they do not.

\section{Parametric Evidence}

A more parametric approach to investigating the relationship between trade, jobs, and firm size is to use regression-based methods. As a first pass at this approach, simple OLS is estimated. Growth rates are regressed on year dummies, firm size dummies, and trade orientation. This approach has several drawbacks and one advantage. Among its drawbacks, there is no theoretical underpinning for the regression nor careful consideration of the properties of the disturbance term, size dummies are almost surely correlated with the disturbance term, the dependent variable only varies between -2 and 2 , and the normality assumption is almost surely wrong. It's advantage is that one is able to estimate conditional correlations. This is no small advantage. During the sample period, macroeconomic shocks were large and important. Disentangling the impact of trade orientation conditional on these shocks is helpful, for while it is indisputable that the macro shocks mattered, it may still be the case that trade orientation also had a systematic impact of jobs. A similar rationale exists for the case of firm size. Conditional on macro shocks, does firm size still seem to be systematically related to job growth?

The parameter estimates of an OLS regression are given in the first column of Table 5. The omitted year is 1980 (which recall contains the employment growth rates from 1979 to 1980), the omitted size quintile is the smallest fifth where size is based on average employment over the life of the firm, and the omitted trade orientation is the export sector. The macroeconomic contraction and subsequent expansion are apparent in the parameter estimates on the year dummies. The precisely estimated and generally increasing in size estimates of the size dummies is consistent with the thesis that size matters and big firms create more jobs. The parameters on trade orientation are statistically insignificant.

The data represent an unbalanced panel of firms, and there are good reasons to suspect that the disturbance term might be correlated within a plant and over time. One way to approach this is to estimate the regression with plant-level fixed effects, and these results are presented in the second column of Table 5. (The size quintile dummy variables are dropped due to the singularity induced when plant fixed effects are introduced.) Column two gives the results with both time and plant fixed effects, but the former are 
included as dummy variables since the parameter estimates on them are of interest. Even with fixed effects, trade orientation simply does not appear to matter, as the coefficients on these variables remains statistically insignificant and close to zero.

The first OLS regression, as well as the nonparametric evidence, suggests that size is correlated with growth. The regression reported in the second column included plant fixed effects, but no measure of plant size. The third and fourth columns report results from the OLS and plant fixed effects regressions when the average number of workers is included as a regressor. (The average number of workers is defined as the average between year $t$ and year $t-1$.) The positive and precisely estimated coefficient on number of workers is again consistent with the notion that larger firms experience more job growth. As importantly, it remains the case that the trade orientation variables just do not matter.

This parametric evidence is quite consistent with the previous nonparametric evidence. The Chilean experience suggests a puzzling pattem when considering links between average employment changes. international trade, and firm size. Firm size seems to matter while whether a firm is in an import-competing or export sector does not.

\section{Simultaneous Job Creation and Job Destruction}

The distributions of job growth rates imply that jobs are being simultaneously created and destroyed. This is not news. Several studies (Dunne, Roberts, and Samuelson (1989), Baldwin, Dunne, and Haltiwanger (1994), Davis and Haltiwanger (1990), and Davis and Haltiwanger (1992)) have shown, using data from industrialized economies, that gross job flows greatly exceed net job flows. There is a lot of chuming, so that jobs are being reallocated even when net job changes at the sectoral level are modest. This phenomenon has also been nicely documented using the same Chilean data in Roberts (1995). In that study, Roberts used methods somewhat different than those used in this paper (following the methodology of Dunne et al. (1989) whereas this paper adopts the approach of Davis and Haltiwanger (1990)). Roberts found that in Chile, Colombia, and Morocco, job reallocation was at least as prevalent as in the industrial economies.

The purpose here is not just to replicate previous findings, but rather to investigate how pattems of job creation and destruction compare across the intemational trade orientation of a sector or, in light of the results from the previous section, across plant size. To express gross job flows as rates, I follow Davis and Haltiwanger and define gross job creation and destruction rates in sector $s$ at time $t$ as:

$$
P O S_{s t}=\sum_{e \in E_{s t}, g_{t t}>0}\left(\frac{x_{e t}}{X_{s t}}\right) g_{e t} \text {, and } N E G_{s t}=\sum_{e \in E_{t 1}, g_{e t}<0}\left(\frac{x_{e t}}{X_{s t}}\right)\left|g_{e t}\right| \text {, }
$$

where $E_{a t}$ is the set of plants in sector $s$ in year $t$ and $X_{s t}$ is average sector employment (defined analogously to average firm employment.) 
The sum of $P O S_{s t}$ and $N E G_{s t}, S U M_{s t}$, measures the gross job reallocation rate in sector $s$ between years $t-1$ and $t$. The net growth rate, $N E T_{s t}$ is given by $P O S_{s t}-N E G_{s t}$, while $M A X_{s t}$ is defined as the maximum of $P O S_{s t}$ and $N E G_{s t}$. (MAX differs from POS or NEG since the maximum of the averages is not the average of the maximums.) SUM and MAX represent upper and lower bounds respectively on the worker reallocation rate necessary to accommodate job reallocation. The top panel in Table 6 gives the annual rates of job creation and destruction (POS and NEG), the net rate of employment growth (NET), the rate of job reallocation (SUM), and a lower bound on the worker reallocation necessary to accommodate the job reallocation (MAX). This part of Table 6 essentially replicates the gist of Roberts (1995). Several messages appear. First, the net rate does indeed hide much of the action. In 1983, for example, the employment rate fell only about two percent, while almost 25 percent of jobs were reallocated. Table 6 also highlights the importance of recognizing firm heterogeneity when thinking about employment issues. Even when employment was shrinking the most (1982), there was concurrent job creation of about five percent. Conversely in 1986, when the weighted average employment growth rate was over 18 percent, the job destruction rate was over nine percent.

The second set of rows in Table 6 looks at job growth rates averaged over sectors defined by trade orientation. For example, the first row in this panel gives the average rates when the average is taken over all firms in export sectors. The net job growth rates indicate while there were losses on the order of two percent for firms in the import and non-tradeables sectors, the net job growth rate in the export sector was about half a percent. This is weak evidence that job growth rates were higher in the export sector following liberalization.

A more subtle message from the second panel in Table 6 concems the political economy of trade liberalization. Almost a third $(31 \%)$ of all jobs were reallocated in the export sector following the liberalization. One might expect that anticipated job growth in the export sector following liberalization would alleviate some of the job-related concems workers in import-competing sectors would feel. But when almost one third of the jobs in the export sector are reallocated, liberalization appears to create much uncertainty about employment outcomes-- even among those who might be expected to most benefit from the liberalization. With 15 percent of export sector jobs destroyed and another 15 percent created, there is so much chuming that it is perhaps not surprising that export sector workers might not find trade liberalization an ex ante appealing prospect. Less surprisingly, workers in import-competing sectors may have good reason to view liberalization with some suspicion. Net job growth was negative and about a quarter of all jobs in the import-competing sector were either created or destroyed. Examining job creation and destruction, instead of just net job creation, helps inform political economic explanations of worker's attitudes towands liberalization. 
The bottom panel in Table 6 looks at job creation and destruction growth rates by the size of the firm (as measured by average employment over the life of the firm). Firms were placed in deciles with the first containing those firms with the smallest average size. It should be noted that due to the very uneven size distribution of firms, firms in the top decile account for almost half of all employment. Again, firm size matters. The job growth rates across size classifications vary much more than across trade classifications. For the decile of the smallest firms, the net job growth rate was -21.3 percent while almost half of all jobs were either destroyed or created. For the largest decile, net job loss was 1.5 percent and less than a quarter of all jobs were reallocated. More generally, as firm size increased, job destruction rates almost monotonically decreased, while job creation rates were relatively flat across size deciles. The real difference between firms of different sizes, then, is due to a difference in job destruction rates.

A comparison of the growth rates by trade orientation and by size shows that variation is much greater with the latter classification. Put another way, if figures in the second panel had applied to three size groups, while the figures for the largest third of the firms applied to export sector firms and figures for the smallest third applied to import-competing firms, most trade economists would not be the least bit surprised.

\section{Persistence of Job Creation and Job Destruction}

The previous sections have documented various aspects of the distribution of job creation and job destruction. This section addresses the persistence of job creation and destruction. Of the jobs created by a firm, what fraction of them were still around after one year? Similarly, of the jobs destroyed, what fraction of those were still gone one year later. This matters, for the benefits of job creation are clearly tempered if these new jobs soon disappear while the costs of job destruction are likewise tempered if firms replace lost jobs soon. Table 7 addresses this issue and divides firms according to trade orientation and average firm size.

The top panel in Table 7 shows that in contractionary years (i.e. 1981), destroyed jobs stay gone, while up to about half of the newly created jobs disappear within a year. On the other hand, in expansionary years (i.e. 1985), the pattem is reversed. About 80 percent of newly created jobs were still around a year later, while only 72 percent of the destroyed jobs were still gone. This suggests that snapshots of job creation and job destruction are potentially misleading. There is a state-dependence in the persistence of job creation and job destruction. Jobs created during an expansion face a rosier prognosis than those created during a contraction, while jobs lost during a contraction are less likely to reappear than those lost during an expansion.

Across trade orientations, there are within-year differences in persistence rates, but no obvious pattems appear. Furthermore, the differences that do appear are typically small. The bottom two panels of Table 7 
give persistence rates for larger firms (more than 20 employees) and smaller firms (the rest). Jobs that are destroyed at smaller firms tend to stay gone at a higher rate. This holds in every year in the sample and in some years the difference is large. (i.e. In 1984 and 1985, the persistence rate of jobs destroyed was between about 17 points higher for smaller firms.) It appears that larger firms are more likely to quickly "re-create" a job that has been destroyed. There is not a similar pattem in the persistence of job creation. (For once,) small and large firms do not seem to differ in any systematic way.

\section{Where Have All the New Jobs Gone?}

As shown above. there was significant simultaneous job creation and destruction. This raises an interesting question. When one looks across sectors of the economy and finds excess job reallocation, what fraction of this reallocation is due to within sector employment shifts and what fraction is due to between sector shifts? An example helps nail down some of these concepts. Suppose the economy is divided into two sectors-- import-competing and exporting. In the import-competing sector, 100 jobs are created while 200 are destroyed. In the exporting sector, 200 jobs are created while 100 are destroyed. The table below summarizes the example.

\begin{tabular}{|l|c|c|c|c|}
\hline Sector & $\begin{array}{c}\text { Jobs } \\
\text { Created }\end{array}$ & $\begin{array}{c}\text { Jobs } \\
\text { Destroyed }\end{array}$ & Sum & Net \\
\hline Import & 100 & 200 & 300 & -100 \\
Export & 200 & 100 & 300 & 100 \\
\hline
\end{tabular}

In the import-competing sector, 300 jobs are created or destroyed for a net loss of 100 jobs. In the export sector, the same number of jobs are created or destroyed for a net gain of 100 jobs. In gross, 600 jobs are created or destroyed while the economy-wide change in net jobs is zero. This results in an excess job reallocation (EXCESS) of 600. It is interesting to then ask, how much of this excess job reallocation is due to within-sector employment shifts and how much is due to between-sector shifts. ${ }^{5}$ In the table above, the export sector gained 100 jobs while the import sector lost 100 . Between-sector job reallocation (BETWEEN) was 200 . The remainder of the excess job reallocation was within-sector (WITHIN.) More generally:

$$
\begin{aligned}
& E X C E S S=\sum_{s} s u m_{s}-\left|\sum_{s} n_{e}\right| \\
& \text { BETWEEN }=\sum_{0} \mid \text { net }_{s}|-| \sum_{0} \text { net }_{s} \mid \\
& W I T H I N=\sum_{s} \text { sum }_{s}-\sum_{s} \mid \text { net }_{s} \mid
\end{aligned}
$$

5 This issue and resulting methods are used in Davis and Haltiwanger (1992). 
where the subscript $s$ refers to the sector of the economy, sum is the sum of jobs created and destroyed, while net is the net change in sector employment. One can compute between and within employment shifts defining sectors in myriad ways. (i.e. By size of plant, by trade orientation, by industry classification or by geographic location.)

Simple models of international trade typically assume full employment and have jobs reallocated from one sector to another. In such a model, liberalization results in workers moving from the import-competing sector to the export sector. All of the excess job reallocation is between-sector, whereas in the above example one third of excess job reallocation is due to between-sector employment shifts.

Table 8 gives the fraction of excess job reallocation due to between group employment shifts over the course of the sample period for different sector definitions. There are 3 groups when the sectors are defined by trade orientation (import-competing, exporting, or non-tradeable). There are 30 groups when sectors are defined by 3-digit (ISIC) industry code. There are 5 groups when plants are grouped by size. In this case, plants are divided into quintiles depending on average employment over the life of the plant. ${ }^{6}$

The striking message of Table 8 is just how very little excess job reallocation is explained by betweensector employment shifts. Indeed, a vast majority of the excess job reallocation is within sectors. When sectors are defined according to a three-digit industry code, about ten percent or less of excess job reallocation is between industries in six of the seven years. The evidence is more stark when plants are divided by average employment. Between zero and three percent of excess job reallocation is accounted for by employment shifts between plants of different size classifications. The most remarkable aspect of Table 8, though, is the inability of trade status to account for any of the between group job reallocation in six of the seven years. What's going on here?

A similar phenomenon has been observed in U.S. plant-level data. ${ }^{7}$ There, the small fraction of excess job reallocation due to between-group employment shifts has been interpreted as suggesting that aggregate macro shocks are much more important than sector-specific shocks. This seems about right. For example, if every sector, however defined, has a net increase (or every sector has a net decrease), then between sector reallocation will be zero. When some sectors have net increases while others have net decreases, there will be some between-sector reallocation. Trade liberalization is typically thought to impact import-competing and exporting sectors quite differentially. Hence, one might have expected to observe significant, or at least non-zero, between sector job reallocation when sectors where defined by their trade orientation. That this

6 In Table 8, plants that either switch 3-digit ISIC codes or switch trade orientation are dropped from the sample. In the case of trade, this meant dropping about 3 percent of the sample, while for the case of industry codes, it meant dropping about 7 percent of the sample. By construction, firms never switch their average size since it is computod over the sample period.

7 See, for example, the discussion in Davis and Haltiwanger (1992). 
was not the case suggests that economy-wide macro shocks very much dominated the impact of the trade liberalization and/or that the impact of trade liberalization on job allocation is poorly captured in traditional models of international trade. Put another way, the tremendous plant-level heterogeneity exhibited in the data really matters when thinking about job reallocation. Predictions about the impact of trade liberalization on jobs perhaps ought to take this heterogeneity into account, for, in the Chilean case anyway, predictions of standard models appear quite at odds with the data.

\section{Jobs, Gender, and Skill Levels}

The analysis so far has treated labor as a homogeneous group and has not distinguished labor by either gender or job type. The Chilean data set, though, contains quite detailed information about the type of labor used in each plant. All of the analyses conducted above with homogeneous labor have been repeated for sub-groups of labor. In particular, separate analyses were done for male and female workers and for white collar versus blue collar workers. In order to avoid "result-overload," the results of these studies are summarized in this section. ${ }^{8}$

The broad discussion on trade and jobs has not addressed the issue of gender. This issue has typically been the domain of labor economics, not international trade, and this seems about right. International economics has very little to say on this subject. One might wonder, though, whether women are more or less likely to lose or gain a job due to international pressures. Similarly, even if net job losses are minimal, are jobs held by women more likely to be reallocated in response to trade and other macroeconomic pressures? Also, are persistence rates similar across gender or are new jobs filled by females more or less likely to persist?

A comparison of mean annual job growth rates for males and females does not yield any obvious patterns. It is the case, though, that the distribution of female employment growth rates is almost always more diffuse than the male counterpart. While eye-balling mean job growth rates does not indicate any obvious differences between males and females, a Wilcoxon ranksum test rejects that the median of the distribution of female job growth rates is the same as that of the males suggesting instead that the distribution of job growth rates for females has a higher median. This shows up in the parametric evidence too. When the percent of the firm's labor force that is female is included in the regressions reported in Table 5, the variable is positive and statistically significant. It's magnitude, though, is very small and suggests that a one percent increase in the fraction of the workforce that is female is conditionally correlated with a one tenth

\footnotetext{
8 Three of the research assistants for this paper have written a detailed report which investigates the role of gender and skill level in great detail. This report is available on Levinsohn's homepage at http://www.econ.lsa.umich.edu/ jamesl and is listed under the working papers. The paper is available in both postscript and .pdf format.
} 
of a percent increase in the job growth rate. This result obtains when one conditions on the skill mix of the firm.

There is much more dramatic evidence of a difference between male and female workforce when one compares gross job reallocation rates (SUM in the previous tables.) These rates are often over twice as high for women than for men. This suggests that the chuming of jobs impacts women much more than men. Because there is no similar difference between gross job reallocation rates for blue and white collar workers (reported below), the difference in gross reallocation rates between men and women is probably more than just a difference in the type of job held by each. Jobs held by women appear to get shuffled around the labor market more.

Finally, the persistence of job creation and destruction for men and women was compared. Just looking at persistence rates for men and women on a year-by-year basis showed no obvious pattems and more formal hypothesis testing rejected any differences in persistence rates by gender.

The census data classified workers into "blue collar" and "white collar" workers. The former are predominately production workers while the latter are mostly managers and owners. Just as comparisons were made above by gender, all the analyses were repeated to try and uncover any systematic differences between blue and white collar workers. In this instance, trade theory does have some predictions. These predictions, though, typically focus on wages and not on jobs. A very nice application of Chilean data to these issues is found in Robbins (1995a), while a broader group of countries is studied in Robbins (1995b). The set of questions addressed in those papers, though, is very different from the set addressed in this paper, as those papers focussed more on Stolper-Samuelson effects.

When comparing net employment growth rates, a few pattems emerge. Job growth rates for blue collar workers fell more quickly as the economy headed into a recession and then recovered before the white collar job growth. The general pattern and magnitude of job growth rates was similar, but the blue collar figures usually led the white collar figures by a year. A Wilcoxon ranksum test rejects that the distributions of white and blue collar job growth rates have the same median, instead suggesting that the median growth rate for blue collar workers is higher. When regressions as in Table 5 were run and the percent of white collar workers at the plant was an included regressor (and also conditioning on the percent of plant workforce that was female), the percent of white collar workers had a negative and statistically significant coefficient. Plants with one percent fewer white collar workers had .002 percent lower job growth. The effect, then, while precisely measured (the coefficient had a t-statistic of about 8 with and without plant fixed effects), is very small. It is worth noting that the inclusion of gender and skill variables in the regressions did not change the results reported in Section 3 concerning the importance of firm size and the unimportance of trade orientation. 
I also find that the gross job reallocation rates are about 10 to 25 percent higher for white collar workers. Finally, the persistence rates for white and blue collar jobs are very similar. In sum, white collar jobs have a (barely) smaller job growth rate than blue collar jobs and have higher reallocation rates, while persistence rates are about the same for the two skill levels.

\section{Conclusions}

As I wrote in the introduction, this paper addresses three issues. The paper is about what researchers can leam of the relationship between jobs and trade using firm-level data. It is about the particular experience of Chile following a broad trade liberalization and spanning significant macroeconomic contraction and expansion. And finally, it is about disceming pattems in the data that might later influence how intemational economists model the interaction between intemational trade and employment. I conclude by briefly addressing each of these in tum, although all are interrelated.

There are several results in this paper that are only attainable with firm-level data. For example, one message of this paper is that firm-size plays an important role in many employment issues, while trade orientation does not. That is, in all the non-parametric evidence and even when conditioning on macroeconomic shocks in the parametric evidence, firm-size matters in a way that trade orientation simply does not. The firm-level data also suggests that the recovery from the recession resulted in a consolidation of employment at larger firms. Firm-level data was required to document the the high level of job "chuming." Finally, firm-level data was necessary to show how the persistence of job creation and destruction varied in systematic ways over time but not by trade orientation. Absent firm-level data, these and other economic relationships would remain hidden.

The paper also addressed the particular experience of Chile. The results are not entirely unexpected. The macroeconomic shocks had major ramifications for employment at the firm-level. Following the liberalization, and during the course of much fluctuations of the real exchange rate, Chilean firms in importcompeting, exporting, and non-tradeable sectors were quite similarly impacted by the macroeconomic shocks. Apparently, the magnitude of these macro shocks was such that they overwhelmed any differential responses to shifts in trade policy. Try as one might, it is difficult to find any differential employment response to the trade liberalization and exchange rate fluctuations. The combination of macroeconomic shocks and trade liberalization resulted in net employment in manufacturing falling by about eight percent. In all years of the sample except 1985, though, about a quarter of all workers changed jobs. If one associates Japan with the notion of lifetime employment, Chile during liberalization is at the other end of the spectrum.

Finally, this paper has reported results that suggest issues to which we as international economists may want to give more thought. In recent years, intemational trade theorists have begun to incorporate the firm 
into their models, and this has resuited in a literature on trade policy with imperfect competition. This literature, though, as well as that which it succeeds, has typically treated firms as homogeneous entities. Firms of course are quite heterogeneous and as one considers how firms respond to changes in their economic environment, firm-level heterogeneity may matter. It certainly matters in the Chilean case. Introducing firm-level heterogeneity into our theoretical models may help bridge the gap between these models and the data. The tremendous chuming of jobs evidenced in this study also reinforces the current trend toward incorporating political economic insights into models of trade policy. All else equal, models with either risk-averse workers and/or labor adjustment costs may well suggest that the job chuming observed in the data, if expected, acts as a force against liberalization. Finally, the results of this study suggest that when contemplating likely results from past and prospective liberalizations, it is important to keep in mind that trade often plays a distant second fiddle to bigger macroeconomic issues. 


\section{References}

Baldwin, J., Dunne, T., and Haltiwanger, J. (1994). A comparison of job creation and destruction between Canada and the United States. Center for Economic Studies Working Paper 94-2, U.S. Bureau of the Census.

Corbo, V., and Sanchez, M. (1985). Adjustment by industrial firms in chile during 1974-82. In Scrambling for Survival-- How firms adjusted tothe recent reforms in Argentina, Chile, and Uraguay, World Bank Staff Working Papers, No. 764.

Davis, S., and Haltiwanger, J. (1990). Gross job creation and destruction: Microeconomic evidence and macroeconomic implications. NBER Macroeconomics Annual, V, 123--168.

Davis, S., and Haltiwanger, J. (1992). Gross job creation, gross job destruction, and employment allocation. Quarterly Journal of Economics, CVII(3), 819--863.

Deardorff, A. V., and Hakura, D. (1994). Trade and wages: What are the questions?. In Bhagwati, J., and Kosters, M. (Eds.), Trade and Wages. American Enterprise Institute, Washington. D.C.

Dunne, T., Roberts, M., and Samuelson. L. (1989). Plant tumover and gross employment flows in the U.S. manufacturing sector. Journal of Labor Economics, 7(1), 48--71.

Krugman, P. (1995). Technology, trade. and factor prices. NBER Working Paper No. 5355.

Krugman, P., and Lawrence, R. (1993). Trade and U.S. wages. NBER Working Paper No. 4478.

Leamer, E. (1994). Trade, wages, and revolving door ideas. NBER Working Paper 4716.

Leamer, E. (1996). In search of Stolper-Samuelson effects on u.s. wages. In Collins, S. (Ed.), Imports, Exports, and the American Worker. The Brookings Instutition, Washington, D.C. (Forthcoming).

Leamer, E., and Levinsohn, J. (1995). Intemational trade theory: The evidence. In Grossman, G., and Rogoff, K. (Eds.), Handbook of International Economics, Vol. III, pp. 1339--1394. North Holland.

Lui, L. (1991). Entry-Exit and Productivity Changes: An Empirical Analysis of Efficiency Frontiers. Ph.D. thesis, University of Michigan.

Robbins, D. (1995a). Trade liberalization and eamings dispersion: Evidence from chile. mimeo, Harvard University.

Robbins, D. (1995b). Trade, trade liberalization and inequality in latin america and east asia: Synthesis of seven country studies. mimeo, Harvard University.

Roberts, M. (1995). Employment flows and producer tumover in three developing countries. Mimeo, Chapter 2 in Roberts and Tybout, op. cit.

Roberts, M., and Tybout, J. (1995). Producer heterogeneity and performance in the semi-industrialized countries. Manuscript, The World Bank.

Silverman, B. (1986). Density Estimation for Statistics and Data Analysis. Chapman and Hall, London.

Sprent, P. (1993). Applied Nonparametric Statistical Methods (Second edition). Chapman and Hall, London.

The World Bank (1989). Industrial finance sector report. Mimeo. 


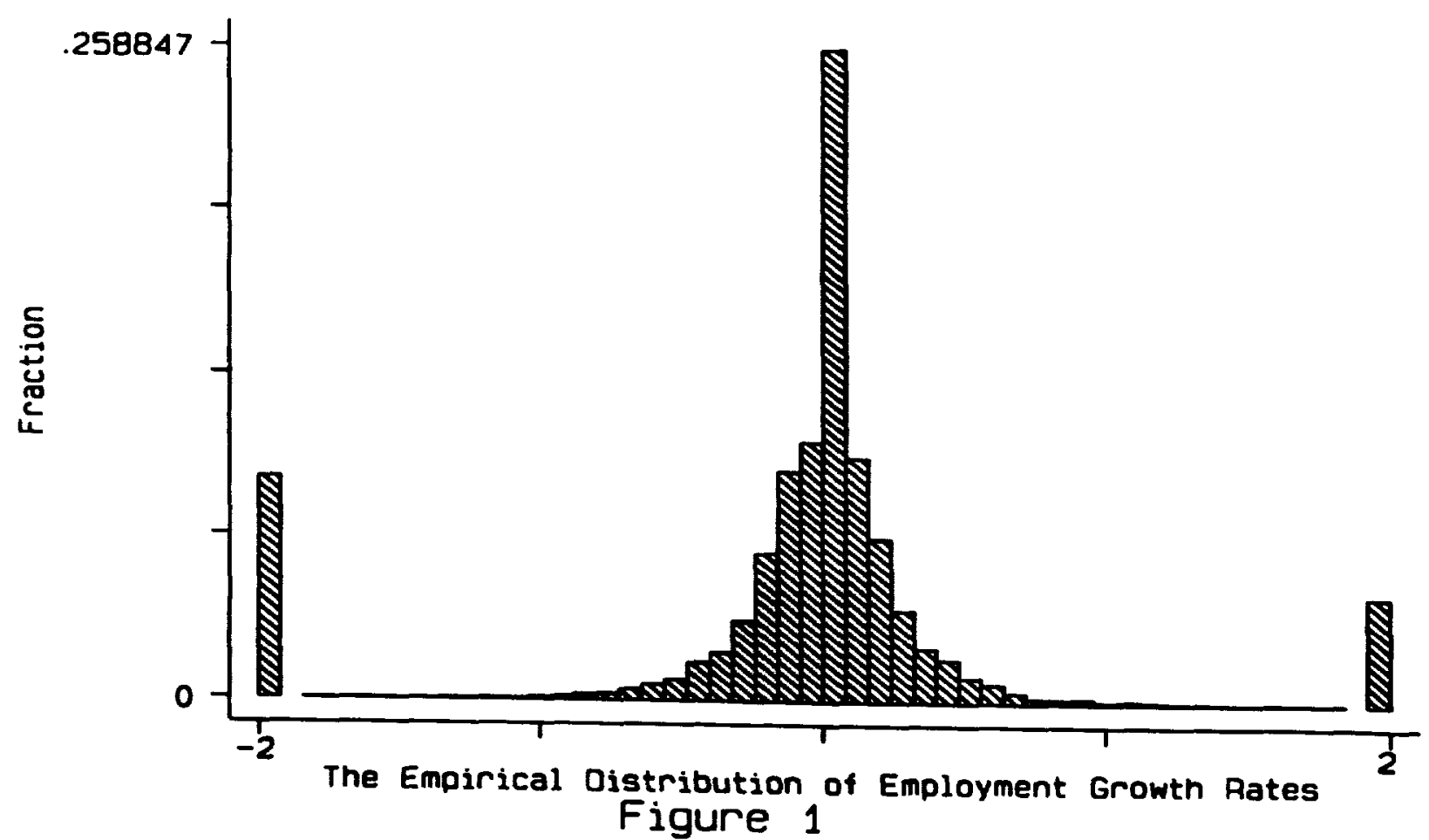




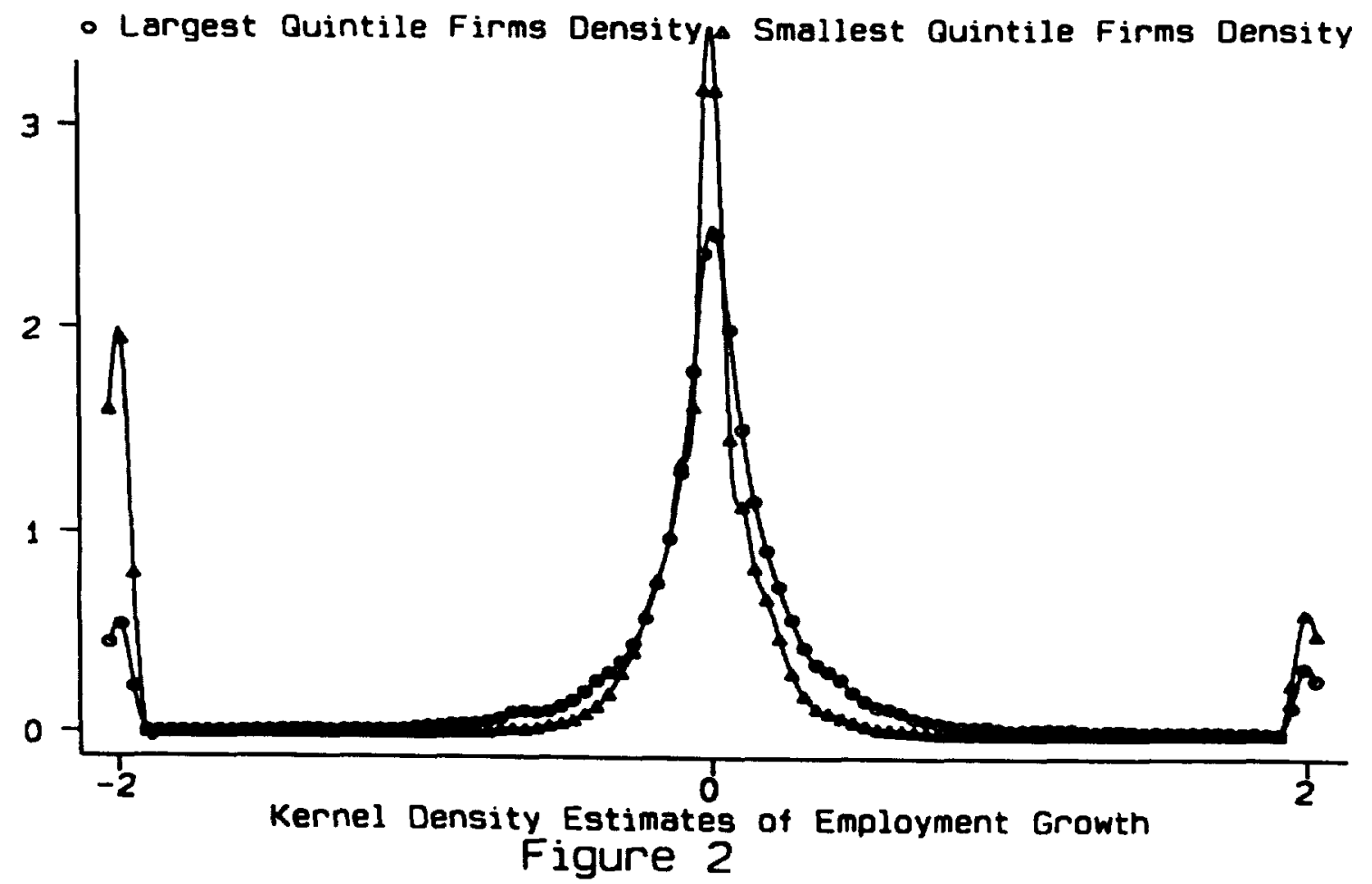


B Fraction of jobs lost

Fraction of jobs created

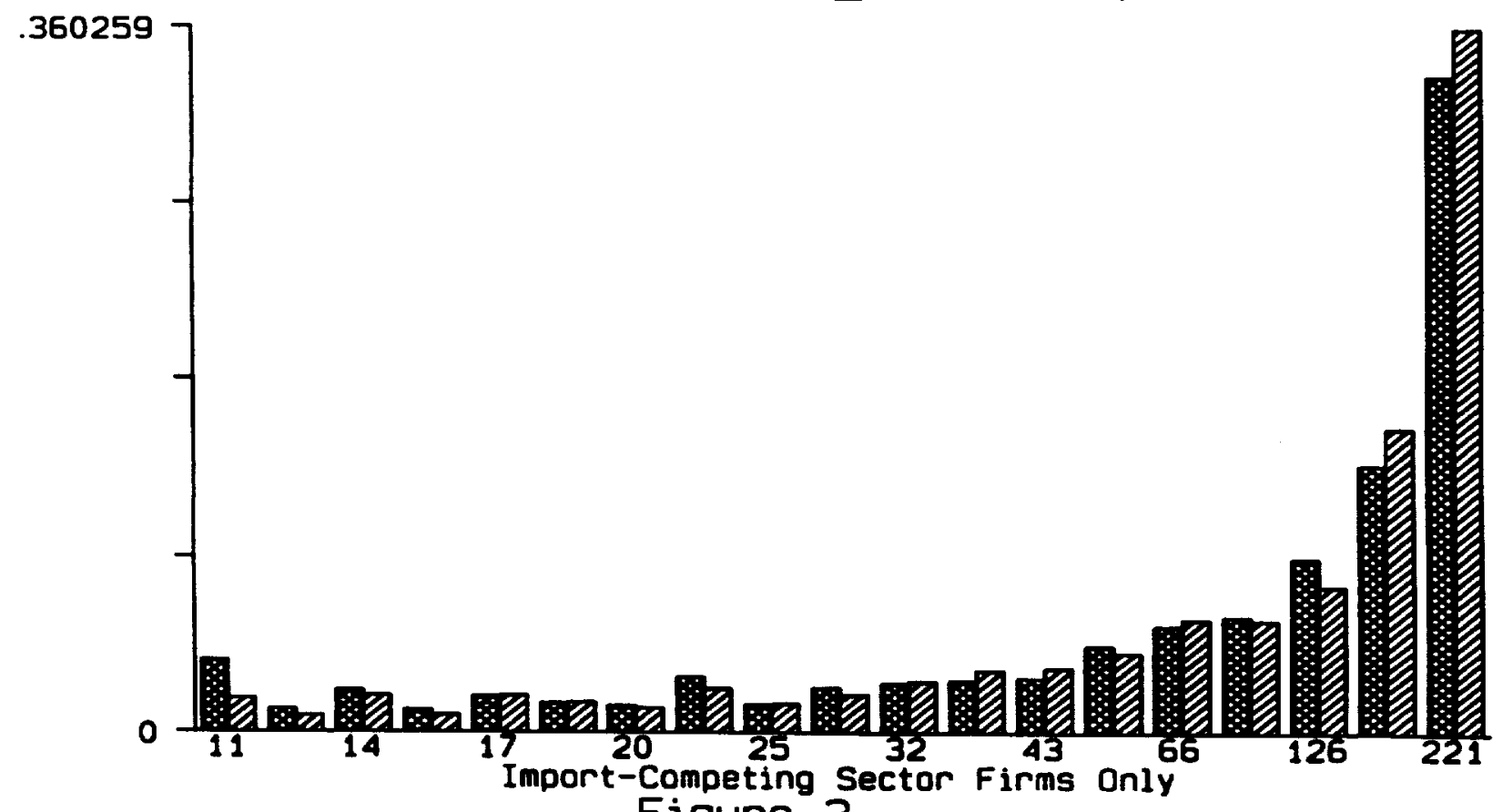

Figure 3 
B Fraction of jobs lost

Fraction of jobs created

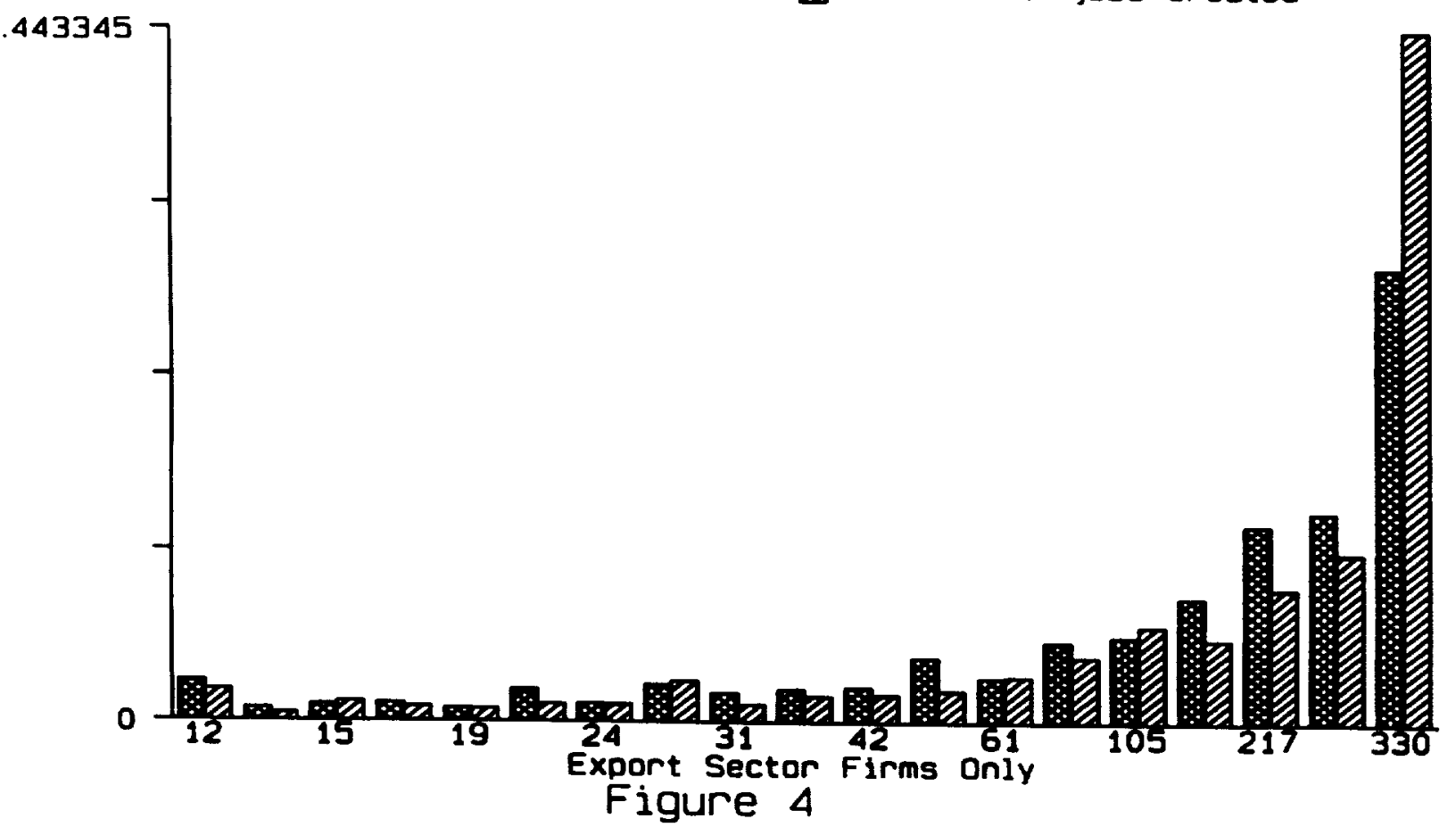


TABLE 1

Chilean Plant-Level Employment

(1979-1986)

\begin{tabular}{|c|c|c|c|c|c|c|}
\hline Year & $\begin{array}{l}\text { Trade } \\
\text { Status }\end{array}$ & $\begin{array}{l}\text { Number } \\
\text { of Plants }\end{array}$ & $\begin{array}{c}\text { Mean } \\
\text { Employment }\end{array}$ & $\begin{array}{l}\text { Standard } \\
\text { Deviation }\end{array}$ & Minimum & Maximum \\
\hline & Export & 750 & 75.8 & 147.5 & 10 & 1470 \\
\hline & Import & 2509 & 58.4 & 120.2 & 10 & 1965 \\
\hline & Non-Traded & 2047 & 42.5 & 138.0 & 10 & 5038 \\
\hline \multirow[t]{4}{*}{1979} & All & 5306 & 54.7 & 131.8 & 10 & 5038 \\
\hline & Export & 670 & 85.9 & 178.0 & 10 & 2209 \\
\hline & Import & 2294 & 58.6 & 109.6 & 10 & 1472 \\
\hline & Non-Traded & 1965 & 43.6 & 138.7 & 10 & 4988 \\
\hline \multirow[t]{4}{*}{1980} & All & 4929 & 56.3 & 133.2 & 10 & 4988 \\
\hline & Expor & 591 & 86.4 & 169.2 & 10 & 2064 \\
\hline & Import & 2090 & 59.7 & 103.9 & 10 & 1321 \\
\hline & Non-Traded & 1831 & 44.5 & 137.7 & 10 & 4701 \\
\hline \multirow[t]{4}{*}{1981} & All & 4512 & 57.0 & 128.9 & 10 & 4701 \\
\hline & Export & 540 & 76.2 & 150.2 & 10 & 1934 \\
\hline & Import & 1890 & 52.4 & 89.1 & 10 & 1279 \\
\hline & Non-Traded & 1720 & 42.9 & 131.1 & 10 & 4373 \\
\hline \multirow[t]{4}{*}{1982} & All & 4150 & 51.6 & 117.4 & 10 & 4373 \\
\hline & Export & 519 & 88.0 & 162.4 & 10 & 1962 \\
\hline & Import & 1751 & 53.6 & 91.8 & 10 & 1249 \\
\hline & Non-Traded & 1630 & 42.2 & 123.7 & 10 & 4066 \\
\hline \multirow[t]{4}{*}{1983} & All & 3900 & 53.4 & 117.9 & 10 & 4066 \\
\hline & Export & 569 & 90.6 & 157.3 & 10 & 1973 \\
\hline & Import & 1823 & 57.5 & 96.3 & 10 & 1242 \\
\hline & Non-Traded & 1580 & 43.9 & 121.2 & 10 & 3944 \\
\hline \multirow[t]{4}{*}{1984} & All & 3972 & 56.8 & 117.7 & 10 & 3944 \\
\hline & Export & 592 & 93.6 & 159.1 & 10 & 2130 \\
\hline & Import & 1804 & 62.4 & 103.7 & 10 & 1424 \\
\hline & Non-Traded & 1549 & 46.7 & 122.6 & 10 & 3895 \\
\hline \multirow[t]{4}{*}{1985} & All & 3945 & 60.9 & 121.8 & 10 & 3895 \\
\hline & Export & 571 & 107.5 & 163.6 & 10 & 1263 \\
\hline & Import & 1778 & 71.5 & 133.1 & 5 & 2163 \\
\hline & Non-Traded & 1502 & 49.2 & 124.3 & 7 & 3865 \\
\hline 1986 & All & 3851 & 68.1 & 136.1 & 5 & 3865 \\
\hline
\end{tabular}




\begin{tabular}{|c|c|c|c|c|c|}
\hline \multicolumn{6}{|c|}{$\begin{array}{c}\text { TABLE } 2 \\
\text { Employment Growth Rates } \\
\text { by Year and Trade }\end{array}$} \\
\hline Year & & $\begin{array}{l}\text { Export } \\
\text { Sector }\end{array}$ & $\begin{array}{l}\text { Import } \\
\text { Sector }\end{array}$ & $\begin{array}{c}\text { Non-Trade } \\
\text { Sector }\end{array}$ & Total \\
\hline 1980 & $\begin{array}{l}\text { mean } \\
\text { s.d. } \\
\text { freq. }\end{array}$ & $\begin{array}{l}-0.20 \\
0.91 \\
789\end{array}$ & $\begin{array}{l}-0.16 \\
0.79 \\
2596\end{array}$ & $\begin{array}{l}-0.07 \\
0.73 \\
2130\end{array}$ & $\begin{array}{l}-0.13 \\
0.79 \\
5515\end{array}$ \\
\hline 1981 & $\begin{array}{l}\text { mean } \\
\text { s.d. } \\
\text { freq. }\end{array}$ & $\begin{array}{c}-0.23 \\
0.86 \\
689\end{array}$ & $\begin{array}{l}-0.18 \\
0.72 \\
2346\end{array}$ & $\begin{array}{l}-0.13 \\
0.64 \\
1992\end{array}$ & $\begin{array}{l}-0.17 \\
0.71 \\
5027\end{array}$ \\
\hline 1982 & $\begin{array}{c}\text { mean } \\
\text { s.d. } \\
\text { freq. }\end{array}$ & $\begin{array}{r}-0.29 \\
0.78 \\
611 \\
\end{array}$ & $\begin{array}{l}-0.31 \\
0.69 \\
2115\end{array}$ & $\begin{array}{c}-0.18 \\
0.68 \\
1884\end{array}$ & $\begin{array}{r}-0.25 \\
0.70 \\
4610\end{array}$ \\
\hline 1983 & $\begin{array}{l}\text { mean } \\
\text { s.d. } \\
\text { freq. }\end{array}$ & $\begin{array}{r}-0.01 \\
0.91 \\
581\end{array}$ & $\begin{array}{l}-0.15 \\
0.80 \\
1974\end{array}$ & $\begin{array}{r}-0.12 \\
0.70 \\
1780\end{array}$ & $\begin{array}{r}-0.12 \\
0.78 \\
4335\end{array}$ \\
\hline 1984 & $\begin{array}{l}\text { mean } \\
\text { s.d. } \\
\text { freq. }\end{array}$ & $\begin{array}{l}0.20 \\
0.99 \\
618\end{array}$ & $\begin{array}{l}0.15 \\
0.85 \\
1954\end{array}$ & $\begin{array}{c}-0.03 \\
0.72 \\
1705\end{array}$ & $\begin{array}{l}0.09 \\
0.83 \\
4277\end{array}$ \\
\hline 1985 & $\begin{array}{c}\text { mean } \\
\text { s.d. } \\
\text { freq. }\end{array}$ & $\begin{array}{l}0.13 \\
0.73 \\
616\end{array}$ & $\begin{array}{l}0.04 \\
0.55 \\
1871\end{array}$ & $\begin{array}{c}-0.01 \\
0.59 \\
1630\end{array}$ & $\begin{array}{l}0.03 \\
0.60 \\
4117\end{array}$ \\
\hline 1986 & $\begin{array}{c}\text { mean } \\
\text { s.d. } \\
\text { freq. }\end{array}$ & $\begin{array}{l}0.02 \\
0.90 \\
635\end{array}$ & $\begin{array}{l}0.05 \\
0.78 \\
1927\end{array}$ & $\begin{array}{c}-0.04 \\
0.74 \\
1630\end{array}$ & $\begin{array}{l}0.01 \\
0.79 \\
4192\end{array}$ \\
\hline Total & $\begin{array}{c}\text { mean } \\
\text { s.d. } \\
\text { freq. }\end{array}$ & $\begin{array}{c}-0.06 \\
0.89 \\
4539\end{array}$ & $\begin{array}{c}-0.09 \\
0.76 \\
14783\end{array}$ & $\begin{array}{c}-0.08 \\
0.69 \\
12751\end{array}$ & $\begin{array}{c}-0.08 \\
0.76 \\
32073\end{array}$ \\
\hline
\end{tabular}




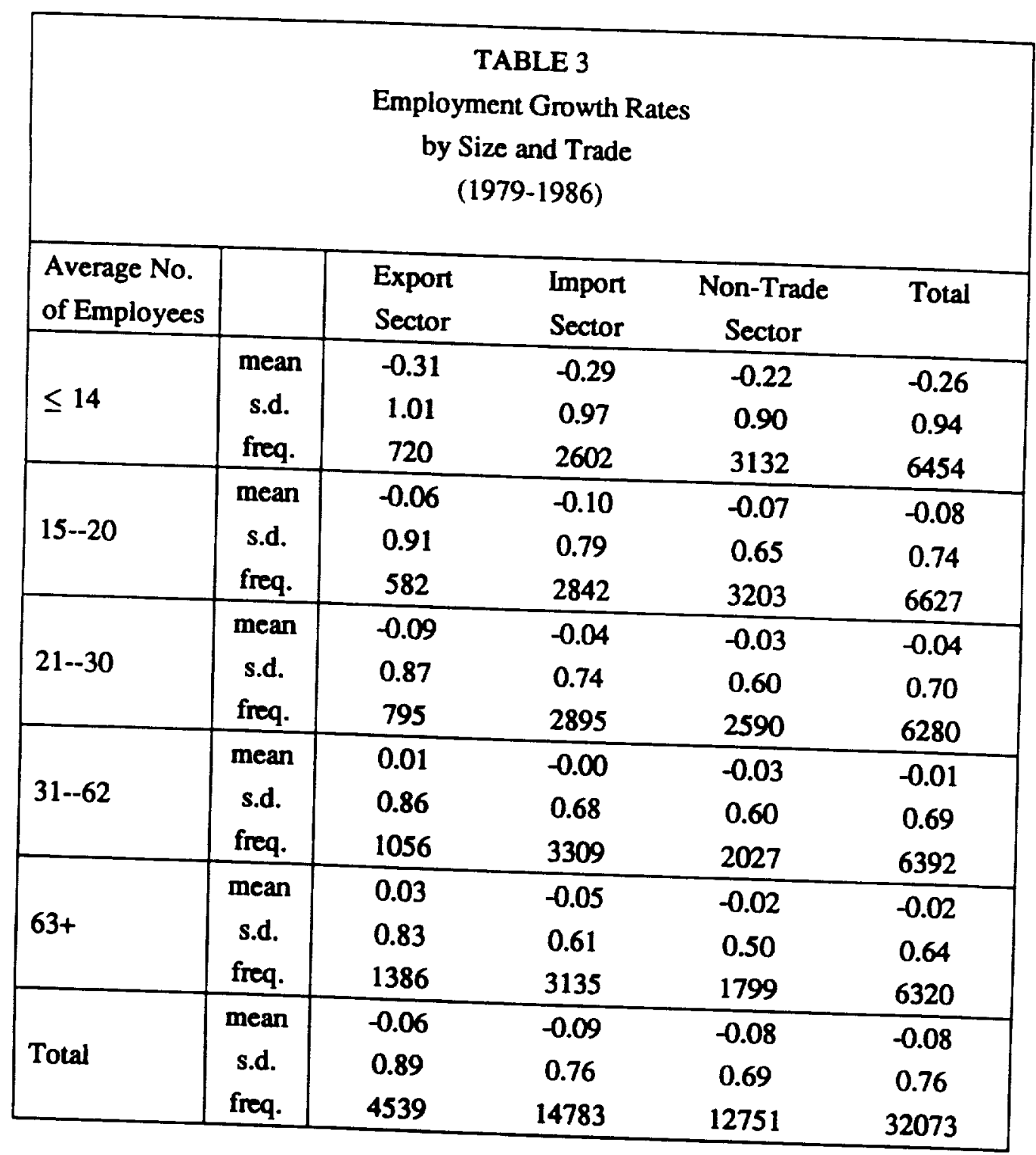
Note: Average number of employees is averaged over the life of the firm. The life of the firm is defined
as the years for which employment was strictly positive. 


\begin{tabular}{|c|c|c|c|}
\hline \multicolumn{4}{|c|}{ TABLE 4 } \\
\hline \multicolumn{4}{|c|}{ Results of Wilcoxon Rank-Sum Test } \\
\hline Group 1 & Group 2 & $z$ & Prob. $>|z|$ \\
\hline Import & Export & 1.16 & .2461 \\
Export & NonTrade & 2.73 & .0063 \\
Import & NonTrade & -2.74 & .0061 \\
Big & Small & 7.21 & .0001 \\
\hline
\end{tabular}




\begin{tabular}{|c|c|c|c|c|}
\hline \multicolumn{5}{|c|}{$\begin{array}{c}\text { TABLE } 5 \\
\text { Results of OLS and Fixed Effects Regressions } \\
\text { (Dependant Variable is Job Growth Rate) }\end{array}$} \\
\hline $\begin{array}{l}\text { Dummy } \\
\text { Variable }\end{array}$ & OLS & $\begin{array}{l}\text { Plant } \\
\text { Fixed } \\
\text { Effects }\end{array}$ & OLS & $\begin{array}{l}\text { Plant } \\
\text { Fixed } \\
\text { Effects }\end{array}$ \\
\hline 1981 & $\begin{array}{r}-0.0418 \\
(-2.887) \\
\end{array}$ & $\begin{array}{c}-.2699 \\
(-21.228)\end{array}$ & $\begin{array}{c}-.0378 \\
(-2.601)\end{array}$ & $\begin{array}{c}-.2681 \\
(-21.093)\end{array}$ \\
\hline 1982 & $\begin{array}{l}-0.1301 \\
(-8.776) \\
\end{array}$ & $\begin{array}{c}-.4721 \\
(-35.769) \\
\end{array}$ & $\begin{array}{c}-.1231 \\
(-8.266) \\
\end{array}$ & $\begin{array}{c}-.4664 \\
(-35.266) \\
\end{array}$ \\
\hline 1983 & $\begin{array}{r}-0.0040 \\
(-0.269) \\
\end{array}$ & $\begin{array}{c}-.4330 \\
(-31.901) \\
\end{array}$ & $\begin{array}{c}.0085 \\
(0.565) \\
\end{array}$ & $\begin{array}{r}-.4234 \\
(-30.998) \\
\end{array}$ \\
\hline 1984 & $\begin{array}{c}0.1984 \\
(13.097) \\
\end{array}$ & $\begin{array}{c}-.3463 \\
(-25.031) \\
\end{array}$ & $\begin{array}{c}.2154 \\
(14.167) \\
\end{array}$ & $\begin{array}{c}-.3379 \\
(-24.321) \\
\end{array}$ \\
\hline 1985 & $\begin{array}{l}0.1436 \\
(9.370) \\
\end{array}$ & $\begin{array}{c}-.4697 \\
(-33.328) \\
\end{array}$ & $\begin{array}{c}.1626 \\
(10.579) \\
\end{array}$ & $\begin{array}{c}-.4652 \\
(-32.986) \\
\end{array}$ \\
\hline 1986 & $\begin{array}{l}0.1186 \\
(7.777) \\
\end{array}$ & $\begin{array}{c}-.6371 \\
(-44.634) \\
\end{array}$ & $\begin{array}{c}.1379 \\
(9.015) \\
\end{array}$ & $\begin{array}{c}-.6363 \\
(-44.611) \\
\end{array}$ \\
\hline 2nd Quintile & $\begin{array}{r}0.1580 \\
(13.672) \\
\end{array}$ & & & \\
\hline 3rd Quintile & $\begin{array}{r}0.1994 \\
(16.512) \\
\end{array}$ & & & \\
\hline 4th Quintile & $\begin{array}{c}0.2134 \\
(14.827) \\
\end{array}$ & & & \\
\hline 5th Quintile & $\begin{array}{c}0.1871 \\
(12.610) \\
\end{array}$ & & & \\
\hline $\begin{array}{l}\text { Average No. } \\
\text { of Workers }\end{array}$ & & & $\begin{array}{c}.0002 \\
(6.750) \\
\end{array}$ & $\begin{array}{c}.0007 \\
(5.938) \\
\end{array}$ \\
\hline Import & $\begin{array}{l}-0.0127 \\
(-1.007) \\
\end{array}$ & $\begin{array}{c}.0434 \\
(0.600)\end{array}$ & $\begin{array}{c}.0155 \\
(-1.222)\end{array}$ & $\begin{array}{c}.0482 \\
(0.667)\end{array}$ \\
\hline Non-Tradeable & $\begin{array}{l}0.0120 \\
(0.921) \\
\end{array}$ & $\begin{array}{c}-.0302 \\
(-0.405) \\
\end{array}$ & $\begin{array}{c}-.0066 \\
(-0.513) \\
\end{array}$ & $\begin{array}{c}-.0283 \\
(-0.3810 \\
\end{array}$ \\
\hline Constant & $\begin{array}{c}-0.2568 \\
(-15.915) \\
\end{array}$ & $\begin{array}{c}.2664 \\
(4.527) \\
\end{array}$ & $\begin{array}{c}-.1318 \\
(-9.025)\end{array}$ & $\begin{array}{c}.2169 \\
(3.653)\end{array}$ \\
\hline
\end{tabular}

Notes: t-statistics are in parentheses. 1980 is the excluded year, the smallest quintile is the excluded size group, and exporting firms are the excluded trade group. 
TABLE 6

Net and Gross Employment Growth Rates

Averages by Year, Trade, and Size

\begin{tabular}{|c|c|c|c|c|c|}
\hline & $N E G_{t}$ & $P^{\prime} S_{t}$ & $S U M_{t}$ & $N E T_{t}$ & $M A X_{t}$ \\
\hline \multicolumn{6}{|c|}{ By Year } \\
\hline 1980 & 0.158 & 0.110 & 0.268 & -0.048 & 0.169 \\
\hline 1981 & 0.165 & 0.083 & 0.248 & -0.082 & 0.167 \\
\hline 1982 & 0.232 & 0.051 & 0.283 & -0.181 & 0.232 \\
\hline 1983 & 0.133 & 0.110 & 0.243 & -0.023 & 0.161 \\
\hline 1984 & 0.089 & 0.168 & 0.257 & 0.079 & 0.172 \\
\hline 1985 & 0.067 & 0.129 & 0.196 & 0.062 & 0.130 \\
\hline 1986 & 0.093 & 0.182 & 0.275 & 0.089 & 0.189 \\
\hline \multicolumn{6}{|c|}{ By Intemational Trade Orientation } \\
\hline Export & 0.152 & 0.158 & 0.310 & 0.006 & 0.209 \\
\hline Impont & 0.139 & 0.119 & 0.258 & -0.019 & 0.182 \\
\hline Non-Tradeable & 0.110 & 0.088 & 0.198 & -0.022 & 0.121 \\
\hline
\end{tabular}

By Decile of Average Employment

\begin{tabular}{|l|lllll|}
\hline 1 (smallest) & 0.348 & 0.135 & 0.483 & -0.213 & 0.348 \\
\hline 2 & 0.213 & 0.097 & 0.310 & -0.115 & 0.213 \\
\hline 3 & 0.178 & 0.115 & 0.293 & -0.064 & 0.188 \\
\hline 4 & 0.154 & 0.122 & 0.276 & -0.032 & 0.179 \\
\hline 5 & 0.138 & 0.111 & 0.249 & -0.027 & 0.157 \\
\hline 6 & 0.144 & 0.127 & 0.270 & -0.017 & 0.173 \\
\hline 7 & 0.144 & 0.138 & 0.282 & -0.006 & 0.186 \\
\hline 8 & 0.136 & 0.150 & 0.286 & 0.014 & 0.186 \\
\hline 9 & 0.135 & 0.143 & 0.278 & 0.008 & 0.183 \\
\hline 10 (largest) & 0.119 & 0.105 & 0.224 & -0.015 & 0.149 \\
\hline
\end{tabular}


TABLE 7

Persistence of (Plant-Level)Jobs Created and Destroyed Fraction Perniating After 1 Year

\begin{tabular}{|c|c|c|c|}
\hline & & $\begin{array}{c}\text { Fraction } \\
\text { Created and } \\
\text { Still There }\end{array}$ & $\begin{array}{c}\text { Fraction } \\
\text { Destroyed and } \\
\text { Still Gone }\end{array}$ \\
\hline \multirow[t]{6}{*}{ All Firms } & 1980 & .661 & .901 \\
\hline & 1981 & .473 & .928 \\
\hline & 1982 & .723 & .871 \\
\hline & 1983 & .796 & .824 \\
\hline & 1984 & .837 & .774 \\
\hline & 1985 & .800 & .728 \\
\hline \multirow[t]{6}{*}{ Export Sector Firms } & 1980 & .646 & .920 \\
\hline & 1981 & .444 & .932 \\
\hline & 1982 & .806 & .808 \\
\hline & 1983 & .770 & .811 \\
\hline & 1984 & .777 & .652 \\
\hline & 1985 & .790 & .649 \\
\hline \multirow[t]{6}{*}{ Import Sector Firms } & 1980 & .653 & .914 \\
\hline & 1981 & .472 & .937 \\
\hline & 1982 & .740 & .888 \\
\hline & 1883 & .819 & .806 \\
\hline & 1984 & .857 & .762 \\
\hline & 1985 & .822 & .712 \\
\hline \multirow[t]{6}{*}{ Nontrade Sector Firm. } & 1980 & .697 & .841 \\
\hline & 1981 & .506 & .900 \\
\hline & 1982 & .633 & .881 \\
\hline & 1983 & .789 & .854 \\
\hline & 1984 & .838 & .856 \\
\hline & 1986 & .730 & .840 \\
\hline \multirow[t]{6}{*}{ Firma $w />20$ employees } & 1980 & .659 & .895 \\
\hline & 1981 & .470 & .924 \\
\hline & 1982 & .739 & .863 \\
\hline & 1983 & .805 & .807 \\
\hline & 1984 & .839 & .744 \\
\hline & 1895 & .807 & .703 \\
\hline \multirow[t]{6}{*}{ Firms $\nabla / \leq 20$ employeed } & 1980 & .680 & .929 \\
\hline & 1881 & .504 & .982 \\
\hline & 1882 & .610 & .931 \\
\hline & 1883 & .716 & .914 \\
\hline & 1984 & .821 & .918 \\
\hline & 1985 & .722 & .874 \\
\hline
\end{tabular}


TABLE 8

Percent of Excess Job Reallocation Due to

Between-Group Employment Shifts (1979-1985)

\begin{tabular}{|l|ccc|}
\hline Year & Industry & $\begin{array}{l}\text { Trade } \\
\text { Status }\end{array}$ & Firm Size \\
\hline $1979-80$ & 10.007 & 0.000 & 0.000 \\
\hline $1980-81$ & 1.848 & 0.000 & 0.000 \\
\hline $1981-82$ & 0.000 & 0.000 & 0.000 \\
\hline $1982-83$ & 25.346 & 21.808 & 0.000 \\
\hline $1983-84$ & 5.106 & 0.000 & 3.209 \\
\hline $1984-85$ & 0.903 & 0.000 & 1.656 \\
\hline $1985-86$ & 6.949 & 0.000 & 0.608 \\
\hline
\end{tabular}

